\title{
Microlunatus phosphovorus gen. nov., sp. nov., a New Gram-Positive Polyphosphate-Accumulating Bacterium Isolated from Activated Sludge
}

\author{
KAZUNORI NAKAMURA, ${ }^{1 *}$ AKIRA HIRAISHI, ${ }^{2}$ YUKIHIKO YOSHIMI, ${ }^{3}$ MAMORU KAWAHARASAKI, ${ }^{1}$ \\ KAZUNARI MASUDA, ${ }^{4}$ AND YOICHI KAMAGATA ${ }^{1}$ \\ National Institute of Bioscience and Human-Technology, Agency of Industrial Science and Technology, 1-1 Tsukuba, \\ Ibaraki 305, ${ }^{1}$ Laboratory of Environmental Biotechnology, Konishi Co., 5-6-3 Yokokawa, Sumida-ku, Tokyo 130, ${ }^{2}$ \\ Tsukuba Laboratory, Taki Chemical Co., Ltd., 2-1-6 Sengen, Tsukuba, Ibaraki 305, ${ }^{3}$ and Shimidzu Institute, \\ Marine Biotechnology Institute Co., Ltd., 1900 Sodeshi, Shimidzu, Shizuoka 424, Japan
}

\begin{abstract}
Polyphosphate-accumulating bacteria that were previously isolated from activated sludge and exhibited high phosphate removal activity were studied taxonomically and phylogenetically. These organisms were grampositive, coccus-shaped, aerobic chemoorganotrophs that had a strictly respiratory type of metabolism in which oxygen was a terminal electron acceptor. They accumulated large amounts of polyphosphate under aerobic conditions. The major quinone was menaquinone $M K-9\left(H_{4}\right)$. The cell wall peptidoglycan contained LLdiaminopimelic acid. The guanine-plus-cytosine content of the DNA was 67.9 mol\%. Our isolates were similar phenotypically and chemotaxonomically to Luteococcus japonicus, which was proposed recently as a new genus and species. However, our isolates differed from $L$. japonicus in cellular fatty acid composition and some other traits. A phylogenetic analysis based on 16S rRNA sequences showed that our isolate differ from the genus Luteococcus and other genera belonging to the high-G+C-content gram-positive group. Accordingly, we concluded that our strain $\mathrm{NM}-1^{\mathrm{T}}$ ( $\mathrm{T}=$ type strain) should be assigned to a new genus and species, for which we propose the name Microlunatus phosphovorus.
\end{abstract}

Activated sludge processes with alternating anaerobic and aerobic conditions have been used widely to eliminate phosphorus from sewage and wastewater. Phosphorus removal in these processes is assumed to be achieved by the dominant growth of polyphosphate-accumulating bacteria in activated sludge. Accordingly, many researchers have isolated polyphosphate-accumulating microorganisms from activated sludge and have characterized these microorganisms to elucidate their roles in biological phosphate removal. Several strains of Acinetobacter species $(6,7,15)$, Arthrobacter globiformis (25), and Pseudomonas sp. (27) have been isolated as polyphosphateaccumulating bacteria. In a previous study we isolated polyphosphate-accumulating bacterial strains which exhibited distinct physiological and taxonomic characteristics $(18,19)$. These isolates are gram-positive cocci that are phenotypically similar to members of the genera Micrococcus and Luteococcus (the latter genus was proposed recently by Tamura et al. [29]). However, the taxonomic position of these new isolates remained unresolved.

In this paper, we describe the results of a taxonomic and phylogenetic study of strain $\mathrm{NM}-1^{\mathrm{T}}(\mathrm{T}=$ type strain). On the basis of these results, we concluded that strain $\mathrm{NM}-1^{\mathrm{T}}$ is a member of a new genus and new species, for which we propose the name Microlunatus phosphovorus. Strain NM-1 is the type strain of Microlunatus phosphovorus.

\section{MATERIALS AND METHODS}

Bacterial strains and culture conditions. Polyphosphate-accumulating strains $\mathrm{NM}^{\mathrm{T}}{ }^{\mathrm{T}}$ (= JCM-9379 $)$ and NM-2 (= JCM-9380), which were isolated from activated sludge, were used in this study (19). These strains were cultured aerobically at $25^{\circ} \mathrm{C}$ in a medium containing (per liter) $0.5 \mathrm{~g}$ of glucose, $0.5 \mathrm{~g}$ of peptone, $0.5 \mathrm{~g}$ of monosodium glutamate, $0.5 \mathrm{~g}$ of yeast extract, $0.44 \mathrm{~g}$ of

* Corresponding author. Mailing address: National Institute of Bioscience and Human-Technology, Agency of Industrial Science and Technology, 1-1 Tsukuba, Ibaraki 305, Japan.
$\mathrm{KH}_{2} \mathrm{PO}_{4}, 0.1 \mathrm{~g}$ of $\left(\mathrm{NH}_{4}\right)_{2} \mathrm{SO}_{4}$, and $0.1 \mathrm{~g}$ of $\mathrm{MgSO}_{4} \cdot 7 \mathrm{H}_{2} \mathrm{O}$. The $\mathrm{pH}$ of the medium was adjusted to 7.0 with a diluted $\mathrm{NaOH}$ solution. Growth was estimated by measuring the optical density at $600 \mathrm{~nm}$ with a spectrophotometer.

Morphological characteristics. Gram staining was performed as described by Magee et al. (16). Morphology was examined by phase-contrast microscopy, scanning electron microscopy, and transmission electron microscopy. For scanning electron microscopy, cultured cells were harvested by centrifugation, washed, and suspended in $20 \mathrm{mM}$ phosphate buffer ( $\mathrm{pH} 7.0$ ). The suspended cells were fixed with $3 \%$ glutaraldehyde, stained with $2 \%$ tannate, and postfixed with $1 \%$ osmium tetroxide. The stained cells were dehydrated in ethanol, and ethanol was replaced with isoamylacetate. After critical point drying, samples were sputter coated with gold and observed with a model JSM-840A scanning electron microscope (JEOL, Ltd., Tokyo, Japan). For transmission microscopy, a centrifuged cell pellet was fixed with $5 \%$ glutaraldehyde and $1 \%$ osmium tetroxide. Ultrathin sections of the sample embedded in epoxy resin were prepared with an ultramicrotome, stained with uranyl acetate and lead citrate, and examined with a model JEM-1200EX transmission electron microscope (JEOL, Ltd.)

Physiological and biochemical characterization. Oxidase activity was determined by monitoring the oxidation of tetramethyl-p-phenylenediamine on filter paper. Catalase activity was determined with a $3 \%$ hydrogen peroxide solution. Nitrate reduction was determined by monitoring nitrite accumulation during anaerobic growth, using medium containing $1.0 \mathrm{~g}$ of $\mathrm{NaNO}_{3}$ per liter. Initial anaerobic conditions were achieved by replacing the gas phase in a test tube with a buthyl rubber stopper with $\mathrm{N}_{2}$. Denitrification was determined by detecting the nitrogen gas produced during anaerobic growth with nitrate. The media used to evaluate utilization of various substrates for growth were prepared by adding 1.8 $\mathrm{g}$ of each substrate to a basal medium ( $\mathrm{pH} 7.0$ ) containing (per liter) $0.1 \mathrm{~g}$ of peptone, $0.1 \mathrm{~g}$ of yeast extract, $0.44 \mathrm{~g}$ of $\mathrm{KH}_{2} \mathrm{PO}_{4}, 0.1 \mathrm{~g}$ of $\left(\mathrm{NH}_{4}\right)_{2} \mathrm{SO}_{4}$, and 0.4 $\mathrm{g}$ of $\mathrm{MgSO}_{4} \cdot 7 \mathrm{H}_{2} \mathrm{O}$. In carbon source utilization tests, the optical density at 600 $\mathrm{nm}$ of a culture after cultivation in each medium was compared with the optical density of a culture grown in basal medium.

Quinone, fatty acids, and cell wall analysis. Quinones were extracted from freeze-dried cells with chloroform-methanol $(2: 1, \mathrm{vol} / \mathrm{vol})$, purified by thin-layer chromatography, and analyzed by reverse-phase high-performance liquid chromatography (HPLC) for identification (10). Mass spectroscopy with a Shimadzu model QP-2000A mass spectrometer and silver-modified thin-layer chromatography were also used for quinone analysis. Whole-cell fatty acids were converted to methyl esters by treatment with anhydrous methanolic $\mathrm{HCl}$, and methyl esters were extracted with $n$-hexane (14). Each prepared sample was analyzed by using a gas-liquid chromatograph equipped with a flame ionization detector (model HP5890; Hewlett-Packard). A gas-liquid chromatography-mass spectrometry analysis was performed with a model HP5970 mass selective detector directly connected to a gas-liquid chromatograph. The presence of diaminopimelic acid 


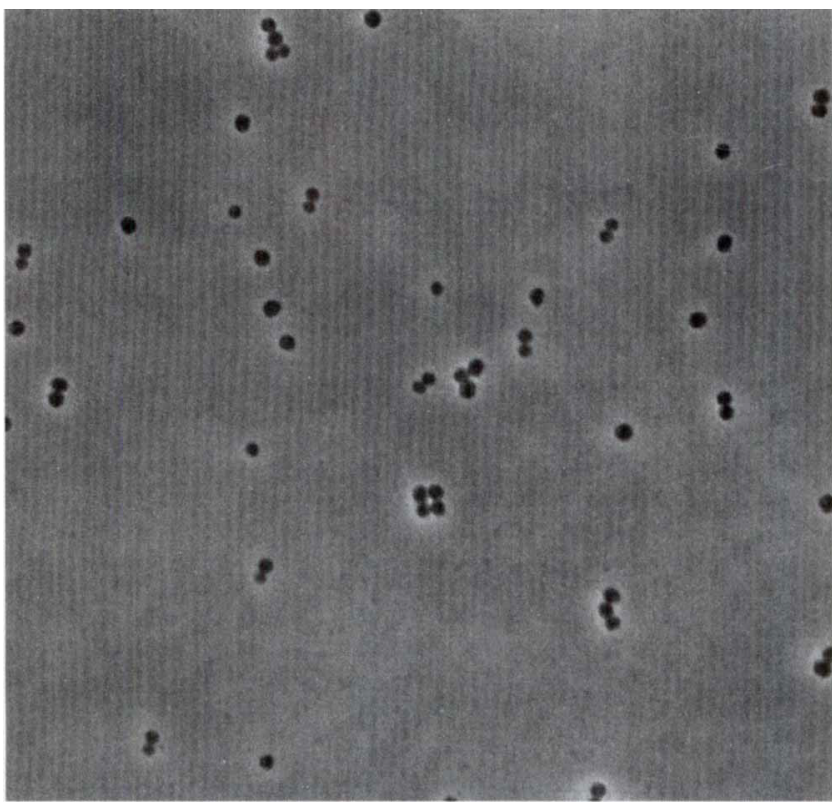

FIG. 1. Phase-contrast photomicrograph of strain NM-1 ${ }^{\mathrm{T}}$. Magnification, $\times 1,000$.

(DAP) isomers in the cell wall peptidoglycan was determined by using thin-layer

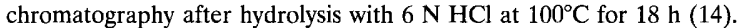

Phosphate uptake measurement. Strain NM-1 ${ }^{\mathrm{T}}$ cells were grown for 2 days, harvested at the late logarithmic phase, washed with distilled water, and then resuspended at a concentration of 2,000 mg (dry weight) of cells per liter. A mixture containing $\mathrm{KH}_{2} \mathrm{PO}_{4}$ and $\mathrm{MgSO}_{4} \cdot 7 \mathrm{H}_{2} \mathrm{O}(2: 1, \mathrm{~mol} / \mathrm{mol})$ was added to the suspended NM-1 ${ }^{\mathrm{T}}$ cells to give a concentration of about $200 \mathrm{mg}$ of phosphorus per liter under aerated conditions, which were maintained by using a glass diffuser and an aeration rate of $1.0 \mathrm{vol} / \mathrm{vol} / \mathrm{min}$. The $\mathrm{pH}$ was kept at 6.8 by using a $\mathrm{pH}$ controller. Phosphate uptake by NM-1 $1^{\mathrm{T}}$ cells was evaluated by monitoring the decrease in the phosphate concentration in the liquid phase. The phosphate concentration was determined by the molybdenum blue method (4).

DNA base composition. DNA was purified by the method of Tamaoka and Komagata (28), as modified by Kamagata and Mikami (12). The guanine-pluscytosine $(\mathrm{G}+\mathrm{C})$ content of DNA was measured by HPLC of the P1 nuclease hydrolysate (12), using a Yamasa GC kit (Yamasa Shoyu Co., Chosi, Japan).

16S rDNA sequencing and phylogenetic analysis. 16S ribosomal DNA (rDNA) fragments that corresponded to positions 8 to 1510 of Escherichia coli 16S rRNA (3) were amplified by PCR directly from protease-digested cell lysates and were purified by agarose gel electrophoresis. PCR-amplified $16 \mathrm{~S}$ rDNA was sequenced by the linear PCR sequencing method, as modified for automated fluorescence detection, and the reaction products were analyzed with a Pharmacia model A.L.F. laser fluorescent DNA sequencer. Information concerning the PCR and sequencing procedures used has been published previously $(9,11)$. Sequences were compiled from overlapping sequence data, and binary sequence similarity values were calculated with the GENETYX computer program (Software Developing Co., Tokyo, Japan). Multiple alignments of the sequences were performed, nucleotide substitution rates $\left(K_{\text {nuc }}\right)$ were calculated, and a neighbor-joining phylogenetic tree $(13,23)$ was constructed by using the CLUSTAL V program (8). Alignment gaps and unidentified base positions were not taken into consideration for the calculations.

Nucleotide sequence accession numbers. The sequences determined in this study have been deposited in the DDBJ, EMBL, and GenBank nucleotide sequence databases under accession numbers D26169 (strain NM-1 ${ }^{\mathrm{T}}$ ) and D26170 (strain NM-2). The accession numbers for the sequences used as reference sequences are as follows: Aeromicrobium erythreum, M37200; Arthrobacter globiformis, M23411; Bacillus subtilis, X60646; Corynebacterium xerosis, M59058; Heliobacterium chlorum, M11212; Luteococcus japonicus, D21245; Micrococcus luteus, M38242; Nocardioides albus, X53211; Nocardioides fastidiosa, X53189; Nocardioides jensenii, X53214; Nocardioides luteus, X53212; Propionibacterium freudenreichii, X53217; Propionibacterium thoenii, X53220; and Streptomyces coelicolor, Y00411 and M35377. The sequence of Propioniferax innocuum (Propionibacterium innocuum) was obtained directly from reference 20.
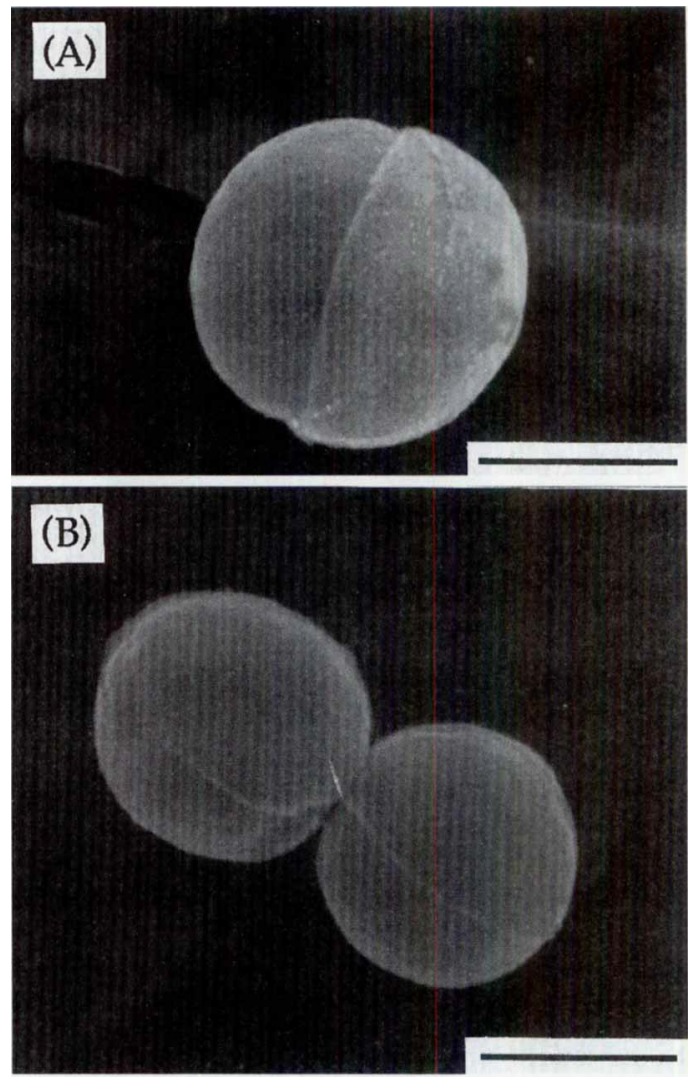

FIG. 2. Scanning electron micrographs of strain $N M-1^{\mathrm{T}}$. (A) Single cell. (B) Pair of cells. Bars $=1 \mu \mathrm{m}$.

\section{RESULTS}

Morphological characteristics. The characteristics of polyphosphate-accumulating strains $\mathrm{NM}-1^{\mathrm{T}}$ and $\mathrm{NM}-2$ were identical, except that the latter strain exhibited flocculent growth. Therefore, the characteristics of strain $\mathrm{NM}-1^{\mathrm{T}}$ are mainly described below. Strain $\mathrm{NM}-1^{\mathrm{T}}$ was a gram-positive, coccus-shaped, nonmotile, non-spore-forming bacterium. The cells were 0.8 to $2.0 \mu \mathrm{m}$ in diameter and occurred singly or in pairs (Fig. 1 and 2). Small irregular clusters of cells were found in some cases. Cell size depended on the growth stage; cells were larger at the early stage of a culture than at the late stationary phase. Rod-shaped or filamentous cells were not observed at any stage of growth. However, cells with a cell wall structure in the middle of the cell and hemispheric cells were observed (Fig. 3), especially during the stationary growth phase. The type of cell division was unusual; thin-section electron microscopy (Fig. 4) revealed a structure like a cell wall in the middle of the cell. Strain NM-2 exhibited strong coagulating activity, and its colonies on agar plates were very hard. In a liquid medium, NM-2 grew as flocs. All other characteristics of strain NM-2 were identical to strain NM-1 ${ }^{\mathrm{T}}$ characteristics.

Cultural characteristics. Strain NM-1 ${ }^{\mathrm{T}}$ exhibited low growth rates even under optimal growth conditions. The doubling time of this strain was about $13 \mathrm{~h}$ in a liquid medium at $\mathrm{pH} 7.0$ and $25^{\circ} \mathrm{C}$. Visible colonies appeared on agar plates after 5 days of incubation. The colonies were circular (diameters, 0.5 to 1 $\mathrm{mm}$ ), smooth, convex, and cream colored at the early stage of growth. After 10 to 14 days of incubation, the colonies were 1 to $2 \mathrm{~mm}$ in diameter and yellowish. 

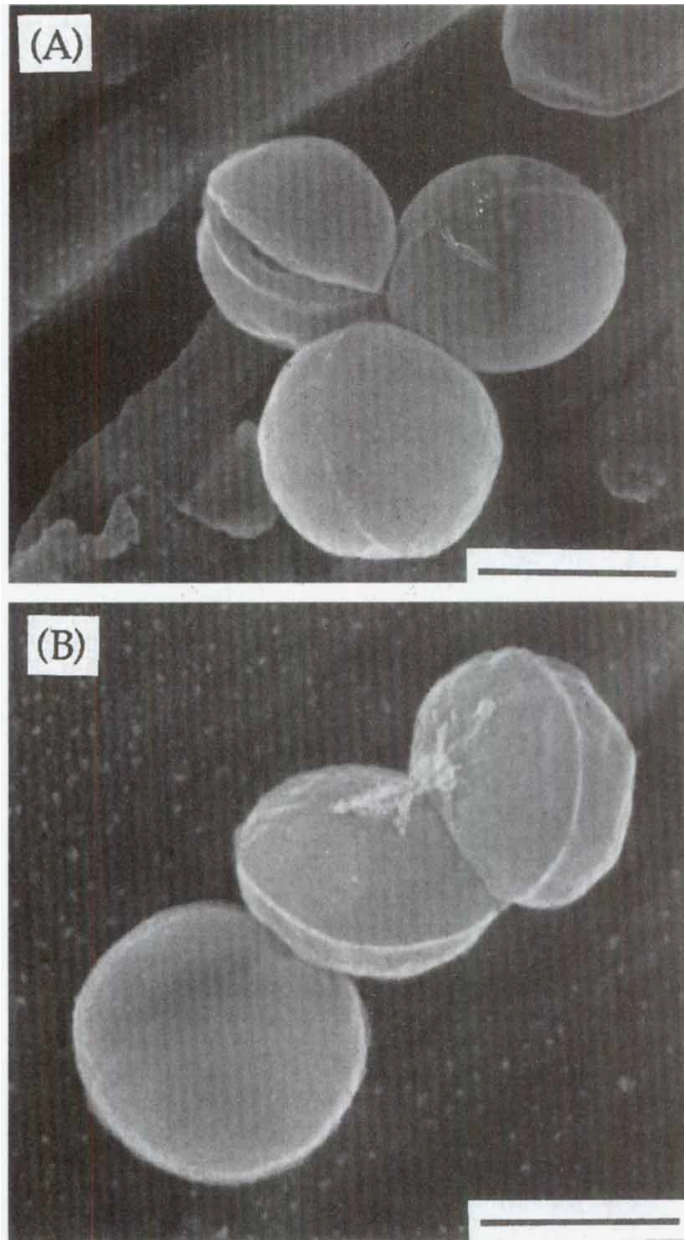

FIG. 3. Scanning electron micrographs of strain NM-1 ${ }^{\mathrm{T}}$. (A) Dividing cell. (B) Divided cell. Bars $=1 \mu \mathrm{m}$.

Phosphorus-accumulating activity. Strain NM-1 ${ }^{\mathrm{T}}$ accumulated large amounts of phosphorus in its cells, as described previously (19). As shown in Fig. 5, cells harvested at the late logarithmic phase exhibited high phosphate-accumulating activity in the absence of any carbon substrate in the medium when they were exposed to exogenous phosphate under aerobic conditions. This resulted in an intracellular phosphorus content of more than $10 \%$ on a dry weight basis (data not shown). This high phosphorus content was found to be responsible for an increase in the polyphosphate fraction content (19). Thin-section electron microscopy revealed a light area which might have consisted of polyphosphate (Fig. 4).

Physiological and biochemical characteristics. The physiological and biochemical characteristics of strain $\mathrm{NM}-1^{\mathrm{T}}$ are as follows. Strain $\mathrm{NM}-1^{\mathrm{T}}$ was an obligately aerobic chemoorganotroph that had a strictly respiratory type of metabolism with oxygen as the terminal electron acceptor. This organism reduced nitrate to nitrite and was able to grow anaerobically with nitrate as a terminal oxidant; it did not grow anaerobically without nitrate. Denitrification was negative. Strain NM-1 was mesophilic and neutrophic. The temperature range for growth was 5 to $35^{\circ} \mathrm{C}$, and the optimum temperature was 25 to $30^{\circ} \mathrm{C}$; strain $\mathrm{NM}-1^{\mathrm{T}}$ did not grow at $40^{\circ} \mathrm{C}$. The $\mathrm{pH}$ range for growth was 5 to 9 , and maximum growth occurred at $\mathrm{pH} 7$; strain $\mathrm{NM}-1^{\mathrm{T}}$ did not grow at $\mathrm{pH} 4$ or 10 . Strain $\mathrm{NM}-1^{\mathrm{T}}$ was not halophilic but was able to grow in the presence of $\mathrm{NaCl}$

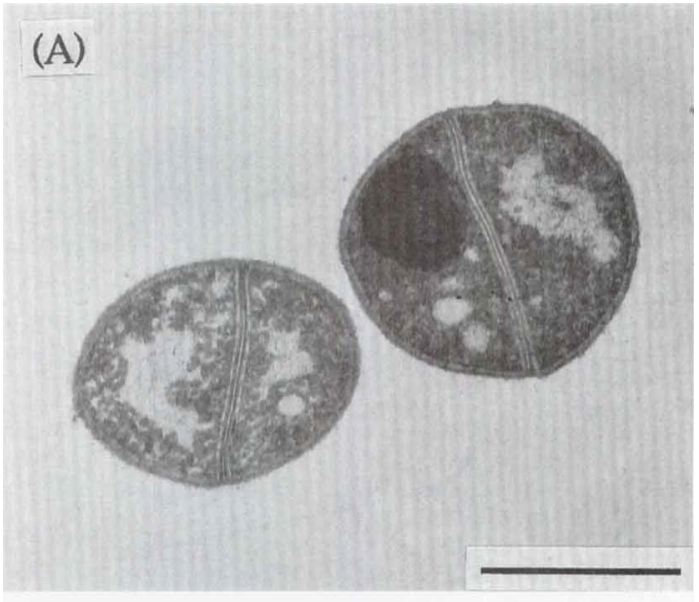

(B)

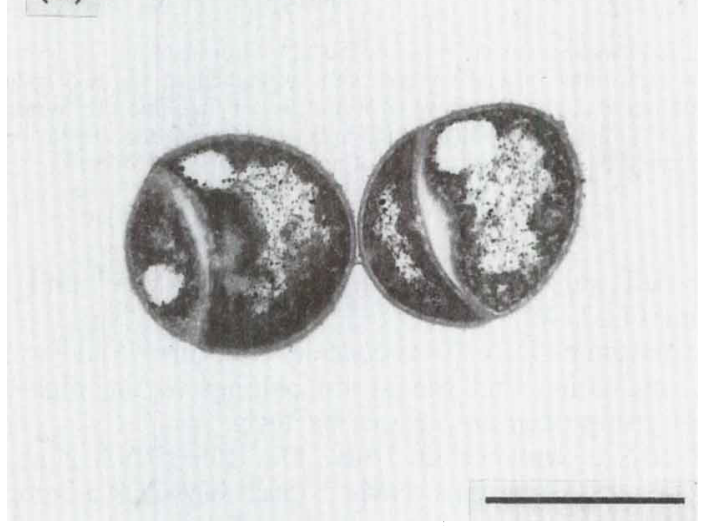

FIG. 4. Transmission electron micrographs of thin sections of strain NM-1 ${ }^{\mathrm{T}}$. (A) Cells harvested at the logarithmic phase. (B) Cells harvested at the stationary phase. Bars $=1 \mu \mathrm{m}$.

concentrations up to $6 \%$; it did not grow in the presence of $7 \%$ $\mathrm{NaCl}$. Catalase was produced. Oxidase activity was positive but weak.

Strain NM-1 ${ }^{\mathrm{T}}$ used a wide variety of organic compounds as carbon and energy sources. Good carbon sources were the sugars glucose, mannose, galactose, xylose, arabinose, saccharose, maltose, cellobiose, trehalose, and melibiose; the sugar alcohols inositol, dulcitol, and mannitol; the organic acids acetate and pyruvate; and the amino acids arginine, asparagine, glutamate, glutamine, and histidine. Starch was also used. The following substrates were not utilized for growth: lactose, glycogen, glycerol, methanol, ethanol, propanol, propionate, succinate, malate, and alanine. Acid was produced from glucose.

Chemotaxonomic characteristics. In a previous study, we reported that strain $\mathrm{NM}-1^{\mathrm{T}}$ had menaquinones with 10 isoprene units (MK-10) as its major quinone components (19). However, careful analysis by HPLC, mass spectrometry, and $\mathrm{Ag}^{+}$-modified thin-layer chromatography revealed that MK$9\left(\mathrm{H}_{4}\right)$ was the predominant menaquinone in strains $\mathrm{NM}-1^{\mathrm{T}}$ and NM-2.

Gas chromatography of the methyl ester derivatives of the fatty acids of the strains revealed that the major components were anteiso- $\mathrm{C}_{15: 0}(31 \%)$, iso- $\mathrm{C}_{15: 0}(24 \%)$, and iso- $\mathrm{C}_{16: 0}$ $(16 \%)$. Smaller but substantial amounts of iso- $\mathrm{C}_{17: 0}(8 \%)$, anteiso- $\mathrm{C}_{14: 0}(4 \%)$, and $\mathrm{C}_{16: 0}(3 \%)$ were also found. 


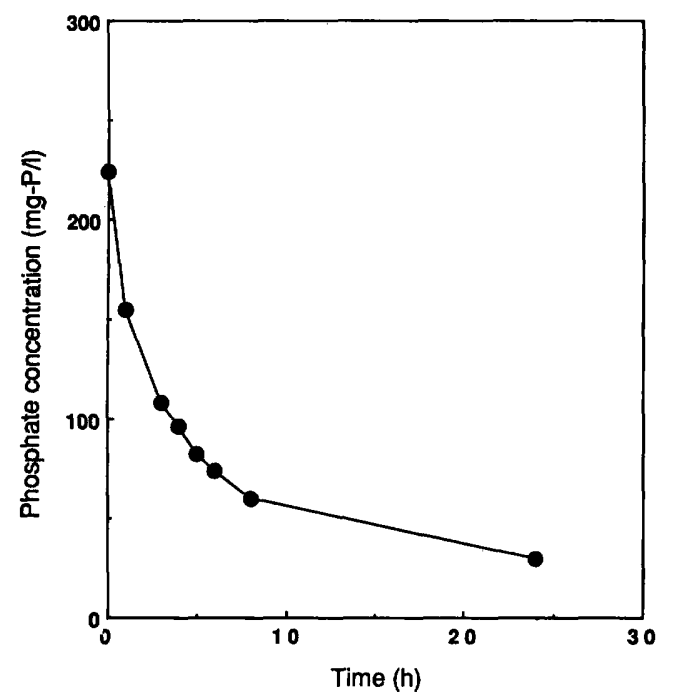

FIG. 5. Phosphate uptake by strain NM-1 ${ }^{\mathrm{T}}$. Strain NM-1 ${ }^{\mathrm{T}}$ was harvested in the late logarithmic phase, washed, and suspended in distilled water at a concentration of 2,000 mg (dry weight) of cells per liter; and then a mixture of $\mathrm{KH}_{2} \mathrm{PO}_{4}$ and $\mathrm{MgSO}_{4} \cdot 7 \mathrm{H}_{2} \mathrm{O}(2: 1, \mathrm{~mol} / \mathrm{mol})$ was added to the suspension under aerobic conditions. The $\mathrm{pH}$ was kept at 6.8 with a $\mathrm{pH}$ controller.

The cell wall peptidoglycan of strains $\mathrm{NM}-1^{\mathrm{T}}$ and $\mathrm{NM}-2$ contained LL-DAP.

The genomic DNA G + C content of strain NM-1 ${ }^{\mathrm{T}}$ was 67.9 mol\%, indicating that this strain belongs to the high-G+Ccontent group of gram-positive bacteria.

16S rDNA sequence analysis. The $16 \mathrm{~S}$ rRNA gene from crude lysates of strains $\mathrm{NM}-\mathbf{1}^{\mathrm{T}}$ and $\mathrm{NM}-2$ was amplified successfully by PCR and was sequenced directly by combining the linear PCR sequencing method and the automated fluorescence detection method. The total length of the fragments, except the PCR primer annealing regions (positions 8 to 27 and 1492 to 1510 ), was 1,418 residues, which accounted for $95 \%$ of the entire 16S rRNA gene. Binary sequence comparisons showed that the sequences of strains $\mathrm{NM}-1^{\mathrm{T}}$ and NM-2 were identical, and these sequences were most similar to the sequence of $N$. jensenii (similarity level, 93.0\%) among the gram-positive species sequences which were available from the databases. The new isolates exhibited similarity levels of 91.0 to $91.8 \%$ with other species of the genus Nocardioides. An equivalent level of similarity $(91.7 \%)$ was also found between our isolates and Aeromicrobium erythreum. We also attempted to compare our sequence data with the sequence data for the phenotypically similar species $L$. japonicus, which was recently described Tamura et al. (29). However, it was difficult to align these sequences accurately, because the previously published sequence for $L$. japonicus is not continuous and large numbers of internal positions (more than 200 bases) have not been determined.

The sequences determined in this study were compared with a data set consisting of 16 sequences for gram-positive species and Escherichia coli, and evolutionary distance $\left(K_{\text {nuc }}\right)$ values were calculated on the basis of the 912 positions that could be aligned (Table 1). Figure 6 shows a neighbor-joining phylogenetic tree constructed on the basis of the $K_{\text {nuc }}$ values obtained. The new isolates formed a lineage distinct from all members of the gram-positive genera compared; Aeromicrobium erythreum and $N$. fastidiosa were the closest phylogenetic neighbors. $L$. japonicus formed a line of descent with Propioniferax innocuum (Propionobacterium innocuum) (32) which was not closely related to the lineage containing our isolates. A similar $16 \mathrm{~S}$ rDNA sequence-based phylogenetic tree was described by Tamura et al. (29).

\section{DISCUSSION}

As reported above, polyphosphate-accumulating strains NM- $1^{\mathrm{T}}$ and NM-2 are gram-positive, non-spore-forming, nonmotile, coccus-shaped, aerobic chemoorganotrophs that belong to the high-G+C-content group of gram-positive bacteria. Also, they are characterized chemotaxonomically by having MK- $9\left(\mathrm{H}_{4}\right)$ as their major quinone, anteiso- $\mathrm{C}_{15: 0}$, iso-C- ${ }_{15: 0}$, and $\mathrm{C}_{16: 0}$ as their major fatty acids, and LL-DAP in their cell walls. Since the phenotypic and chemotaxonomic properties of our two strains are identical, except for floc formation, they must belong to a single species. This view is supported by the finding that the $16 \mathrm{~S}$ rDNA sequences of the two strains are identical.

Thus far, the following six genera of gram-positive cocci which belong to the high-G+C-content group have been validly described: the genera Deinococcus (2), Kineococcus (31), Luteococcus (29), Micrococcus (24, 26), Pelczaria (21), and Stomatococcus (1). Among these genera, however, only members of the genus Luteococcus contain MK-9 $\left(\mathrm{H}_{4}\right)$ and LL-DAP and have chemotaxonomic characteristics that are also found in the isolates which we studied. The genus Luteococcus was recently proposed for gram-positive nonmotile cocci having the chemotaxonomic traits described above and a $\mathrm{G}+\mathrm{C}$ content of ca. $67 \mathrm{~mol} \%$; this genus is monotypic, and the type and only species is L. japonicus. Although our strains are quite similar to $L$. japonicus in phenotypic and chemotaxonomic characteristics, we found major differences. The most pronounced dissimilarity is that our isolates contain branched, saturated fatty acids with anteiso- $\mathrm{C}_{15: 0}$, iso- $\mathrm{C}_{15: 0}$, and iso- $\mathrm{C}_{16: 0}$ as the primary components, whereas $L$. japonicus has unsaturated $\mathrm{C}_{16}, \mathrm{C}_{17}$, and $\mathrm{C}_{18}$ as its major fatty acids. Our isolates also differ from $L$. japonicus in requiring strictly aerobic conditions for growth, in reducing nitrate to nitrite, and in accumulating large amounts of polyphosphate.

Our phylogenetic analysis based on 16S rRNA gene sequence information demonstrated that strains $\mathrm{NM}-1^{\mathrm{T}}$ and NM-2 are most closely related to species belonging to the genera Nocardioides and Aeromicrobium but are on a line of descent distinct from the previously described gram-positive bacteria. The levels of binary sequence similarity between the new isolates and related species having high DNA $\mathrm{G}+\mathrm{C}$ contents are less than $93 \%$. This value appears to be low enough to warrant classification of our isolates in a separate new genus. We paid special attention to $L$. japonicus because of its phenotypic and chemotaxonomic similarities to the new isolates, but the phylogenetic data clearly showed that the two taxa diverge at the generic level.

Our isolates produce coccoid cells but resemble the rodshaped species Aeromicrobium erythreum (17) and N. fastidiosa (5) in their chemotaxonomic properties, as all of these organisms contain MK-9 $\left(\mathrm{H}_{4}\right)$ as the major quinone and LL-DAP in their cell walls. This is interesting because Aeromicrobium erythreum and $N$. fastidiosa are the closest relatives of our isolates on the phylogenetic tree. Close genetic relationships between coccus- and rod-shaped species have been found previously (e.g., Micrococcus luteus and Arthrobacter globiformis) (26). This suggests that morphological characteristics are much less important phylogenetically than chemotaxonomic traits in the gram-positive bacteria. The relatively close affinity between our isolates and species belonging to the genera Nocardioides (22) and Aeromicrobium may create interest in 


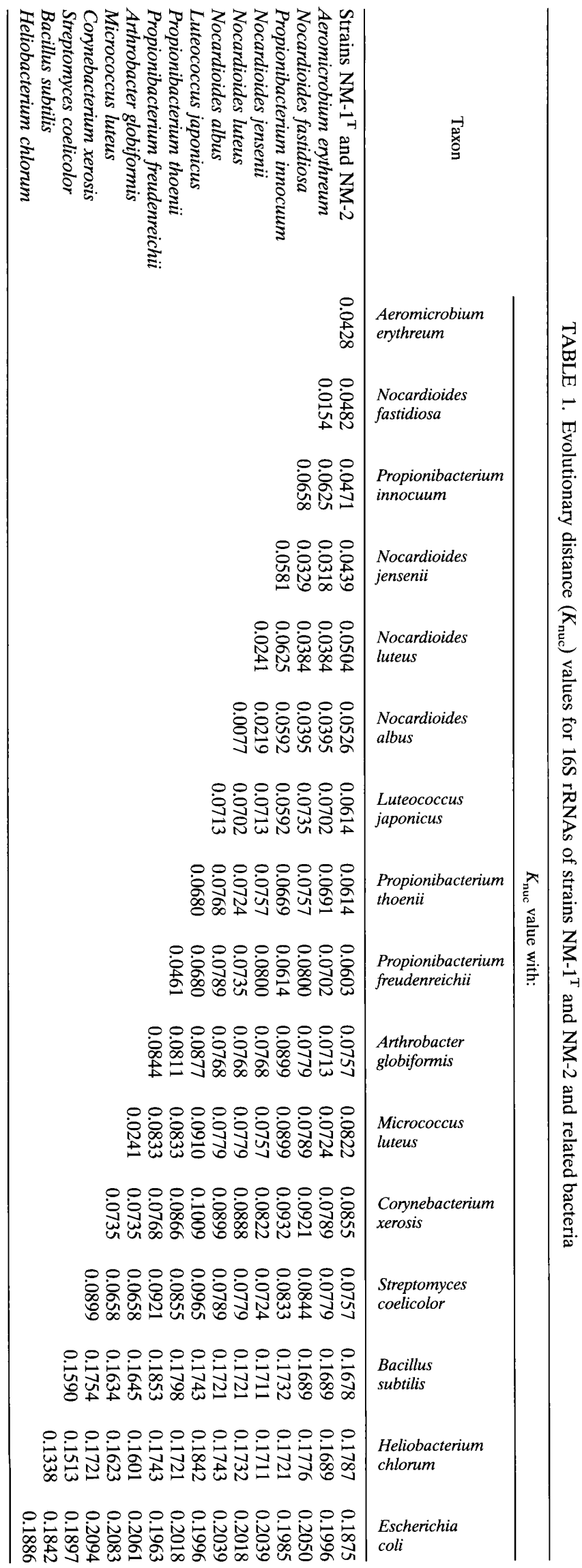

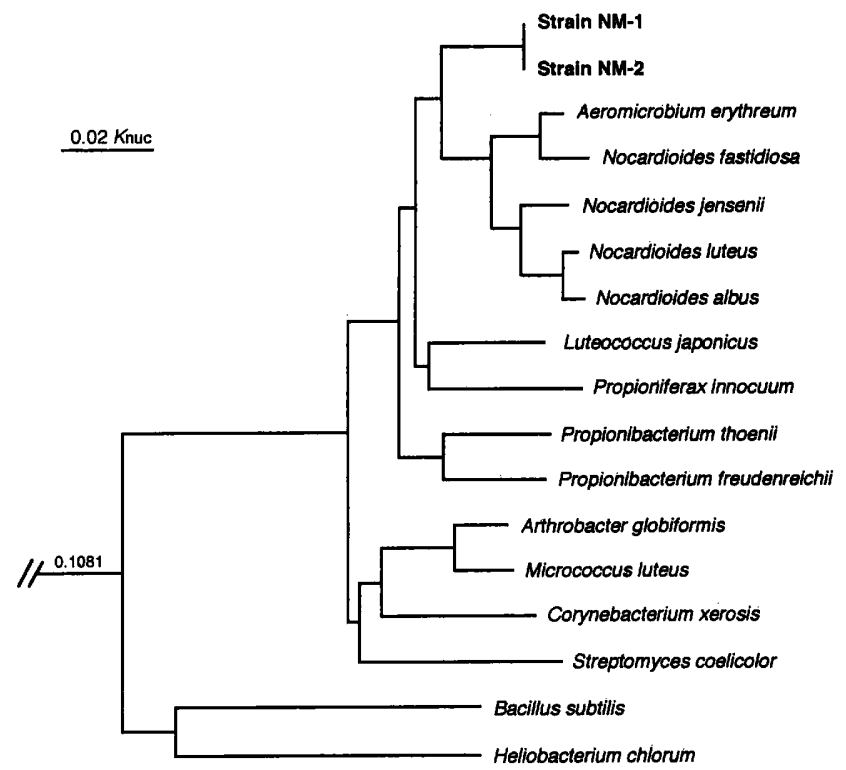

FIG. 6. Unrooted distance matrix tree showing phylogenetic relationships among strains NM-1 $1^{\mathrm{T}}$ and NM-2 and related bacteria. Bar $=0.02 K_{\text {nuc }}$.

the ability of members of these genera to accumulate polyphosphate. In this connection, it is worth noting that gram-positive bacteria with high DNA $\mathrm{G}+\mathrm{C}$ contents were recently reported to play a possible major role in biological phosphate removal (30).

On the basis of the results of our phenotypic, chemotaxonomic, and phylogenetic studies, we concluded that the polyphosphate-accumulating strains which we studied should be placed in a new genus and new species of gram-positive bacteria. For these isolates, we propose the name Microlunatus phosphovorus gen. nov., sp. nov., and we designate strain NM-1 the type strain. Descriptions of the new genus and species are given below.

Description of Microlunatus gen. nov. Microlunatus (Mi. cro.lu.na'tus. Gr. adj. micros, small; M. L. n. lunatus, half moon; M. L. n. Microlunatus, small moon-like microorganism) cells are spherical (diameter, 0.8 to $2.0 \mu \mathrm{m}$ ) and occur singly, in pairs, or in some cases in clusters. The cells often have a cell wall structure in the middle of the cell and are hemispherical, especially at the stationary growth phase. Nonmotile. Spores are not formed. Gram positive. Aerobic and chemoorganotrophic, having a strictly respiratory type of metabolism with oxygen as the terminal electron acceptor. The growth rate is low. Catalase positive. Oxidase positive but weak. The cells reduce nitrate to nitrite but do not reduce nitrite to nitrogen.

The major quinone is $\mathrm{MK}-9\left(\mathrm{H}_{4}\right)$. The cell wall peptidoglycan contains LL-DAP. The major fatty acids are anteiso- $\mathrm{C}_{15: 0}$, iso- $\mathrm{C}_{15: 0}$, and iso- $\mathrm{C}_{16: 0}$. The $\mathrm{G}+\mathrm{C}$ content of the DNA is 67.9 mol\%. The phylogenetic position is in the high-G+C-content group of gram-positive bacteria; the genera Aeromicrobium and Nocardioides are the closest relatives.

The type species is Microlunatus phosphovorus.

Description of Microlunatus phosphovorus sp. nov. Microlunatus phosphovorus (phos.pho'vo.rus. M. L. phosphorus, phosphorus; L. v. vorus, devour; M.L. adj. phosphovorus, phosphorus-accumulating microorganism). The morphology of this species and its chemotaxonomic characteristics are the same as those described above for the genus. Catalase positive. Oxidase positive but weak. The cells reduce nitrate to nitrite but do not 
reduce nitrite to nitrogen. The doubling time is about $13 \mathrm{~h}$ in a liquid medium. The phosphorus content of the cells may be extremely high (sometimes more than $10 \%$, wt/wt), depending on the cultural conditions. The cells utilize glucose, mannose, galactose, xylose, arabinose, saccharose, maltose, cellobiose, trehalose, and melibiose, but not lactose. Starch is utilized, but glycogen is not utilized. Sugar alcohols such as inositol, dulcitol and mannitol are utilized. Alcohols like methanol, ethanol, propanol, and glycerol are not utilized. Among the fatty acids, pyruvate is utilized and acetate is utilized slowly. The optimum growth temperature is $25^{\circ} \mathrm{C}$. The optimum $\mathrm{pH}$ is 7.0 .

Occurs in activated sludge processes with alternating anaerobic and aerobic conditions.

The type strain is strain NM-1, which has been deposited in the Japan Collection of Microorganism (RIKEN) as strain JCM-9379.

\section{ACKNOWLEDGMENTS}

We thank Akemi Ohmiya and Satoko Kanematsu, Fruit Tree Research Station, Ministry of Agriculture, Forest and Fisheries, for help with electron microscopy, Yoshikuni Urushigawa, National Institute for Resources and Environment, Agency of Industrial Science and Technology, for help with the fatty acid analysis, and Ken-ichiro Suzuki, Japan Collection of Microorganisms (RIKEN) for advice concerning taxonomy.

\section{REFERENCES}

1. Bergan, T., and M. Kocur. 1982. Stomatococcus mucilaginosus gen. nov., sp. rev., a member of the family Micrococcaceae. Int. J. Syst. Bacteriol. 32:374377.

2. Brooks, B. W., and R. G. E. Murray, 1981. Nomenclature for "Micrococcus radiodurans" and other radiation-resistant cocci: Deinococcaceae fam. nov. and Deinococcus gen. nov., including five species. Int. J. Syst. Bacteriol. 31:353-360.

3. Brosius, J., J. L. Palmer, J. P. Kennedy, and H. F. Noller. 1978. Complete nucleotide sequence of a $16 \mathrm{~S}$ ribosomal RNA gene from Escherichia coli. Proc. Natl. Acad. Sci. USA 75:4801-4805.

4. Callaway, J. O. 1989. Determination of inorganic nonmetalic constituents, p. 4-175-4-176. In L. S. Clesceli (ed.), Standard methods for the examination of water and wastewater, 17 th ed. American Public Health Association, Washington, D.C.

5. Collins, M. D., and E. Stackebrandt. 1989. Molecular taxonomic studies on some LL-diaminopimelic acid-containing coryneforms from herbage: description of Nocardioides fastidiosa sp. nov. FEMS Microbiol. Lett. 57:289-294.

6. Dainema, M. H., M. van Loosdrecht, and A. Scholten. 1985. Some physiological characteristics of Acinetobacter spp. accumulating large amounts of phosphate. Water Sci. Technol. 17:119-125.

7. Fuhs, C. W., and M. Chen. 1975. Microbial basis of phosphate removal in the activated sludge process for the treatment of wastewater. Microb. Ecol. 2: 119-138.

8. Higgines, D. G., A. J. Bleasby, and R. Fuchs. 1992. CLUSTAL V: improved software for multiple sequence alignment. Comput. Appl. Biosci. 8:189-191.

9. Hiraishi, A. 1992. Direct automated sequencing of 16S rDNA amplified by polymerase chain reaction from bacterial cultures without DNA purification. Lett. Appl. Microbiol. 15:210-213.

10. Hiraishi, A., Y. K. Shin, and J. Sugiyama. 1992. Rapid profiling of bacterial quinones by two-dimensional thin-layer chromatography. Lett. Appl. Microbiol. 14:170-173.

11. Hiraishi, A., Y. K. Shin, Y. Ueda, and J. Sugiyama. 1994. Automated sequencing of PCR-amplified 16S rDNA on 'Hydrolink' gels. J. Microbiol. Methods 19:145-154.

12. Kamagata, Y., and E. Mikami. 1991. Isolation and characterization of a novel thermophilic Methanosaeta strain. Int. J. Syst. Bacteriol. 41:191-196.

13. Kimura, M. 1980 . A simple method for estimating evolutionary rates of base substitution through comparative studies of nucleotide sequences. J. Mol. Evol. 16:111-120.

14. Komagata, K., and K. Suzuki. 1987. Lipid and cell-wall analysis in bacterial systematics. Methods Microbiol. 19:161-207.

15. Lowson, E. N., and N. E. Tonhazy. 1980. Changes in morphology and phosphate uptake patterns of Acinetobacter calcoaceticus strains. Water S A (Pretoria) 6:105-112

16. Magee, C. M., G. Rodeheaver, and R. F. Edgerton. 1975. A more reliable Gram staining technique for diagnosis of surgical infections. Am. J. Surg. 130:341-346

17. Miller, E. S., C. R. Woese, and S. Brenner. 1991. Description of the erythromycin-producing bacterium Arthrobacter sp. strain NRRL B-3381 as Aeromicrobium gen. nov., sp. nov. Int. J. Syst. Bacteriol. 41:363-368.

18. Nakamura, K., K. Masuda, and E. Mikami. 1989. Polyphosphate accumulating bacteria and their ecological characteristics in activated sludge process, p. 427-431. In T. Hattori, et al. (ed.), Recent advances in microbial ecology. Japan Scientific Societies Press, Tokyo.

19. Nakamura, K., K. Masuda, and E. Mikami. 1991. Isolation of a new type of polyphosphate accumulating bacterium and its phosphate removal characteristics. J. Ferment. Technol. 4:258-263.

20. Pitcher, D. G., and M. D. Collins. 1991. Phylogenetic analysis of some LL-diaminopimelic acid-containing coryneform bacteria from human skin: description of Propionibacterium innocuum sp. nov. FEMS Microbiol. Lett. 84:295-300.

21. Poston, J. M. 1976. Pelczaria aurantia gen. nov., sp. nov., a newly described orange-colored bacterium. Arch. Microbiol. 160:114-120.

22. Prauser, H. 1976. Nocardioides, a new genus of the order Actinomycetales. Int. J. Syst. Bacteriol, 26:58-65.

23. Satiou, N., and M. Nei. 1987. The neighbor-joining method: a new method for reconstructing phylogenetic trees. Mol. Biol. Evol. 4:406-425.

24. Schleifer, K. H. 1986. Section 12. Gram-positive cocci, p. 999-1103. In P. H. A. Sneath, N. S. Mair, M. E. Sharpe, and J. G. Holt (ed.), Bergey's manual of systematic bacteriology, vol. 4. The Williams \& Wilkins Co., Baltimore.

25. Shoda, M., T. Ohsumi, and S. Udaka. 1980. Screening for high phosphate accumulating bacteria. Agric. Biol. Chem. 44:319-324.

26. Stackebrandt, E., and C. R. Woese. 1979. A phylogenetic dissection of the family Micrococcaceae. Curr. Microbiol. 2:317-322.

27. Suresh, N., R. Warburg, M. Timmerman, J. Wells, M. Coccia, M. F. Roberts, and H. O. Halvorson. 1985. New strategies for the isolation of microorganisms responsible for phosphate accumulation. Water Sci. Technol. 17(11/12): $43-56$.

28. Tamaoka, J., and K. Komagata. 1984. Determination of DNA base composition by reversed-phase high-performance liquid chromatography. FEMS Microbiol. Lett. 25:125-128.

29. Tamura, T., M. Takeuchi, and A. Yokota. 1994. Luteococcus japonicus gen. nov., sp. nov., a new gram-positive coccus with LL-diaminopimelic acid in the cell wall. Int. J. Syst. Bacteriol. 44:348-356.

30. Wagner, M., R. Erhart, W. Manz, R. Amann, H. Lemmer, D. Wedi, and K.-H. Schleifer. 1994. Development of an rRNA-targeted oligonucleotide probe specific for the genus Acinetobacter and its application for in situ monitoring in activated sludge. Appl. Environ. Microbiol. 60:792-800.

31. Yokota, A., T. Tamura, T. Nishii, and T. Hasegawa. 1993. Kineococcus aurantiacus gen. nov., sp. nov., a new aerobic, gram-positive, motile coccus with meso-diaminopimelic acid and arabinogalactan in the cell wall. Int. J. Syst. Bacteriol. 43:52-57.

32. Yokota, A., T. Tamura, M. Takeuchi, N. Weiss, and E. Stackebrandt. 1994. Transfer of Propionibacterium innocuum Pitcher and Collins 1991 to Propioniferax gen. nov, as Propioniferax innocuum comb. nov. Int. J. Syst. Bacteriol. 44:579-582. 